\title{
OCCUPATIONAL RISK FACTORS ASSOCIATED WITH PERCEIVED CENTRAL NERVOUS SYSTEM DISORDER AMONG PRINTING INDUSTRY WORKERS IN MEDAN
}

\author{
Samuel Marganda, Taufik Ashar, Nurmaini \\ Department of Environmental Health, Faculty of Public Health, \\ Universitas Sumatera Utara
}

\begin{abstract}
Background: Toluene is a colorless, water-insoluble liquid, aromatic hydrocarbon, with the smell associated with paint thinners. Toluene is used in the printing of colored illustrations in media such as catalogues and magazines. Studies on male employees in the printing industry found that both high and low exposure to toluene were associated with an imbalance of sexual hormones in serum samples. This study aimed to analyze the occupational risk factors associated with perceived central nervous system disorder attributable to toluene exposure among printing industry workers in Medan, North Sumatera.

Subjects and Method: This was a cross sectional study conducted at a printing industry in Medan, North Sumatera. A sample of 50 printing industry workers was selected for this study. The dependent variable was perceived central nervous system disorder attributable to toluene. The independent variables were age, smoking, years of service, history of illness, alcohol consumption, and personal protective equipment (PPE). The data were collected by questionnaire and analyzed by a chi-square test.

Results: Perceived central nervous system disorder attributable to toluene exposure was statistically associated with age and smoking, but was not statistically associated with years of service, history of illness, alcohol consumption, and PPE.

Conclusion: Perceived central nervous system disorder is statistically associated with age and smoking among printing workers.
\end{abstract}

Keywords: perceived central nervous system disorder, toluene, age, smoking, printing workers.

\section{Correspondence:}

Samuel Marganda. Department of Environmental Health, Faculty of Public Health, Universitas Sumatera Utara, Medan, North Sumatera.

Email: samuelmarganda@yahoo.co.id. Mobile: 085362985340. 